\title{
PENGARUH SISTEM PENGENDALIAN INTERN TERHADAP KINERJA APARATUR PEMERINTAHAN NAGARI DALAM PENGELOLAAN KEUANGAN NAGARI
}

\author{
Octavia Malinda \\ Jurusan Administrasi Publik, Fakultas Ilmu sosial, Universitas Negeri Padang \\ Email: octaviamalinda@yahoo.co.id \\ Syamsir \\ Jurusan Administrasi Publik, Fakultas Ilmu Sosial, Universitas Negeri Padang \\ Email: syamsirsaili@yahoo.com
}

\begin{abstract}
The purpose of this study was to analyze the effect of internal control system on the performance of nagari apparatus in nagari financial management in Tanah Datar Regency. This study was a quantitative research with associative method. The population of this study was all nagari apparatus in Tanah Datar Regency, which numbered 600 people. Sample inthis study was consisted of 248 nagari apparatus determined with Slovin formula. Besides, samplein this study determined through multistage random sampling technique. Data in this study were collected through questionnaires with Likert scale measurement distributed to respondents. The data were then analyzed using multiple linear regression. The results of this study indicated that internal control system (in the planning, implementation, administration, reporting, and accountability stages, together and partially), had a significant effect on the performance of nagari apparatus in managing nagari financial in Tanah Datar Regency. So that it could be concluded that the internal control system of nagari apparatus had a significant effect on the performance of nagari apparatus in nagari financial management in Tanah Datar Regency.
\end{abstract}

Keywords: Internal control system, job performance, nagari financial management

\section{Pendahuluan}

UU No. 6 Tahun 2014 tentang Desa, Desa diberikan kesempatan besar untuk mengurus tata pemerintahannya sendiri serta pelaksanaan pembangunan untuk meningkatkan kesejahteraan dan kualitas hidup masyarakat desa. Selain itu, pemerintah desa diharapkan untuk lebih mandiri dalam mengelola pemerintahan dan berbagai sumber daya alam yang dimiliki, termasuk di dalamnya pengelolaan keuangan dan kekayaan milik desa. Begitu besar peran yang diterima oleh desa, tentunya disertai dengan tanggung jawab yang besar pula. Oleh karena itu, pemerintah desa harus bisa menerapkan prinsip akuntabilitas dalam tata pemerintahannya, dimana semua akhir kegiatan penyelenggaraan pemerintahan desa harus dapat dipertanggungjawabkan kepada masyarakat desa sesuai dengan ketentuan. 
jmiap.ppj.unp.ac.id
Email : jianfis.unp@gmail.com

Vol.2 No.1 Maret 2019
Menurut Permendagri No. 113 Tahun 2014 Pasal 1 Ayat 6, Pengelolaan Keuangan Desa adalah keseluruhan kegiatan yang meliputi perencanaan, pelaksanaan, penatausahaan, pelaporan, dan pertanggung jawaban keuangan desa. Sedangkan menurut Permendagri No. 13 Tahun 2006 Pasal 1 Ayat 8, Pengelolaan Keuangan Daerah adalah keseluruhan kegiatan yang meliputi perencanaan, pelaksanaan, penatausahaan, pelaporan, pertanggungjawaban, dan pengawasan keuangan.

Menurut Permendagri No. 113 Tahun 2014 pasal 2 ayat 1 bahwa Keuangan desa dikelola berdasarkan asas-asas transparan, akuntabel, partisipatif serta dilakukan dengan tertib dan disiplin anggaran. Dalam pengelolaan keuangan di Kabupaten Tanah Datar ditemukan adanya permasalahan yaitu tidak adanya transparansi aset Nagari seperti kebun Nagari yang keuangannya tidak jelas, dana DAUN (Dana Alokasi Umum Nagari) yang sampai sekarang tidak ada kejelasan terhadap masyarakat. Informasi yang ditemukan di website www.wartaandalas.com, salah satu kasus dalam pengelolaan keuangan nagari adalah ditemukannya indikasi kecurangankecurangan mulai dari pemasalahan ketidaktransparanan keuangan, aset nagari sampai masalah kinerja para staff di kantor Walinagari Sugayang. Permasalahan serupa juga terjadi di Nagari III Koto, adanya keterlambatan atau kesulitan dalam penyusunan perencanaan dan pelaporan keuangan desa serta mereka juga kurang memahami tugasnya dalam pengelolaan keuangan Nagari.

Sistem pengendalian intern adalah hal yang penting dan harus diperhatikan dalam menentukan kinerja aparatur pemerintahan karena seorang

pimpinan dalam menjalankan tugas dan tanggungjawabnya dipengaruhi oleh sistem pengendalian intern. Sistem pengendalian intern menjadi faktor yang mendorong agar kinerja pegawai menjadi lebih baik dan bertanggungjawab. Idealnya sistem pengendalian intern dari pimpinan ke seluruh pegawai harus dilakukan terus-menerus agar tujuan organisasi tercapai secara efektif dan efesien. Menurut PP No. 60 Tahun 2008 Mengenai Sistem Pengendalian Intern Pemerintah (SPIP), pengendalian Intern adalah proses yang integral pada tindakan dan kegiatan yang dilakukan secara terus menerus oleh pimpinan dan seluruh pegawai untuk memberikan keyakinan memadai atas tercapainya tujuan organisasi melalui kegiatan yang efektif dan efisien, keandalan pelaporan keuangan, pengamanan aset negara, dan ketaatan terhadap peraturan perundangundangan.

Namun pada kenyataanya, berdasarkan hasil wawancara pendahuluan pada hari Selasa tanggal 15 Mei 2018, menurut Kaur Pembangunan Nagari Padang Ganting masih ada kendala yang dihadapi dalam pengelolaan keuangan dan terlalu banyaknya prosedur sehingga menyulitkan dalam sistem pelaporan keuangan. Selain itu, menurut Sekretaris Nagari Padang Ganting dan Kaur Pembangunan Nagari Padang Magek bahwa mereka kurang paham dengan aturan yang selalu berubah-rubah dan berbelit-belit. Kemudian, Kaur Keuangan Nagari Padang Magek, Kaur Keuangan Nagari Barulak, Kaur Pemerintahan Nagari Aia Angek dan kaur perekonomian Nagari Aia Angek mengatakan bahwa perlu adanya pelatihan pengelolaan keuangan kembali, agar mereka lebih paham dalam pengelolaan keuangan. Selain itu, Kaur Perekonomian Nagari Padang Magek 
jmiap.ppj.unp.ac.id
Email : jianfis.unp@gmail.com

Vol.2 No.1 Maret 2019 juga mengatakan kurangnya keterbukaan pengelolaan keuangan Nagari dan masih adanya pengelompokan-pengelompokan antar karyawan dalam pengelolaan keuangan Nagari.

Selanjutnya menurut kaur pemerintahan dan kaur pembangunan Nagari Padang Magek, mereka berharap adanya pelatihan khusus bagi Perangkat Nagari dalam pengelolaan keuangan. Selain itu, menurut Walinagari Batipuh Baruh dan kaur perekonomian Nagari Salimpauang bahwa sering terlambatnya informasi sampai di kantor Walinagari. Selain itu, menurut Walinagari Baringin dan Walinagari Aia Angek bahwa pemeriksaan intern terhadap pengelolaan keuangan Nagari jarang dilakukan serta kekurangan kualitas dan kuantitas SDM. Di samping itu, Walinagari III Koto juga menjelaskan masih kurangnya keterampilan perangkat nagari serta Bendahara Nagari belum pernah mengikuti diklat. Disamping itu, Kaur Kesejahteraan dan Kaur Pembangunan Nagari III Koto menjelaskan pula kurangnya kapasitas dan personalia nagari dalam pengelolaan keuangan, dimana kondisi ini terlihat dari adanya keterlambatan atau kesulitan dalam penyusunan perencanaan dan pelaporan keuangan desa serta mereka juga kurang memahami tugasnya dalam pengelolaan keuangan Nagari. Selain itu, menurut sekretaris dan Kaur umum Nagari III Koto, Bendahara Nagari tidak memahami sistem keuangan nagari, kurang menguasai komputer serta kurang tanggap dalam mengelola keuangan nagari. Begitu juga infomasi dari Walinagari Pandai Sikek, beliau menjelaskan bahwa birokrasi nagari kurang sehat, bimbingan kerja tidak ada, serta orientasi kerja lebih pada dokumentasi dari pada hasil.
Berdasarkan persoalan yang telah dijabarkan di atas, dapat dipahami banyaknya permasalahan yang dihadapi oleh aparatur pemerintahan nagari terutama dalam pengelolaan keuangan, maka peneliti tertarik untuk meneliti pengaruh sistem pengendalian intern terhadap kinerja aparatur pemerintahan nagari dalam pengelolaan keuangan nagari di Kabupaten Tanah Datar. Penelitian ini merupakan intisari dari hasil penelitian skripsi dan merupakan bagian dari penelitian payung dari Syamsir (2018) dengan judul Model Pembinaan Aparatur Pemerintahan Nagari dalam Pengelolaan Keuangan Nagari di Kabupaten Tanah Datar. Sedangkan Rumusan masalah yang ingin dijawab dalam penelitian ini yaitu : Apakah terdapat pengaruh pengendalian intern (secara simultan dan parsial) dalam tahap perencanaan, pelaksanaan, penatausahaan, pelaporan, dan pertanggungjawaban terhadap kinerja aparatur pemerintahan nagari dalam pengelolaan keuangan nagari di Kabupaten Tanah Datar?

\section{Tinjauan Kepustakaan}

\section{Pengelolaan Keuangan Nagari}

UU No. 6 Tahun 2014 tentang Desa, maka pemerintahan desa ikut dalam mengelola keuangan dan mempertanggungjawabkannya.

Sedangkan menurut UU No. 6 Tahun 2014 pasal 1 Ayat 10 Keuangan Desa adalah hak dan kewajiban desa dapat dinilai dengan uang serta segala sesuatu berupa uang dan barang yang berhubungan dengan pelaksanaan hak dan kewajiban desa.

Di Indonesia Pedoman Pengelolaan Keuangan Desa diatur dalam Permendagri No. 113 Tahun 2014 Pasal 1 
jmiap.ppj.unp.ac.id
Email : jianfis.unp@gmail.com

Vol.2 No.1 Maret 2019
Ayat 6 menyebutkan Pengelolaan Keuangan Desa adalah keseluruhan kegiatan yang meliputi perencanaan, pelaksanaan, penatausahaan, pelaporan, dan pertanggung jawaban keuangan desa. Sedangkan Rohmansjah (2015 : 3) keuangan desa diartikan sebagai semua hak dan kewajiban desa yang dapat dinilai dengan uang maupun barang yang dapat dijadikan milik desa berhubung dengan pelaksanaan hak dan kewajiban tersebut. Keuangan desa pada dasarnya merupakan sub sistem dari keuangan negara sebagaimana di atur dalam UU No. 17 Tahun 2003 tentang Keuangan Negara.

Menurut Muhammad (2007 : 32) kegiatan pengelolaan keuangan desa meliputi perencanaan, penganggaran, penatausahaan, pelaporan, pertanggung jawaban, dan pengawasan keuangan desa. Jadi bisa disimpulkan bahwa pengelolaan keuangan desa merupakan kegiatan yang meliputi perancanaan, penganggaran penatausahaan, pelaporan, pertanggung jawaban kepala desa maupun perangkat desa dalam mengelola keuangan desa. Menurut PP No. 47 Tahun 2015 tentang Peraturan Pelaksanaan UU No. 6 Tahun 2014 pasal 1 ayat 8 yang di maksud dengan dana desa adalah dana yang bersumber dari anggaran pendapatan dan belanja negara yang diperuntukan bagi desa yang di trasnfer melalui anggaran pendapatan dan belanja daerah kabupaten/kota dan digunakan untuk membiayai pemerintahan, pembangunan, penyelenggaraan pelaksanaan, pembinaan kemasyarakatan, dan pemberdayaan masyarakat.

Selanjutnya menurut Rozali (2011) sumber pendapatan desa terdiri atas pendapatan asli desa dan bantuan dari pemerintah kabupaten. Pendapatan asli desa meliputi hasil usaha desa, hasil kekayaan desa, hasil swadaya dan partisipasi, hasil gotong-royong dan lainlain pendapatan desa yang sah. Selain itu bantuan pemerintah kabupaten terdiri atas bagian dari perolehan pajak dan retribusi daerah, dana perimbangan keuangan pusat dan daerah yang diterima oleh pemerintah kabupaten, bantuan dari pemerintah dan pemerintah provinsi, sumbangan dari pihak ketiga, dan pinjaman desa. Sedangkan kekayaan desa terdiri dari tanah kas desa, pasar desa, bangunan desa, obyek rekreasi yang diurus oleh desa, hutan desa, tempattempat pemancingan di sungai, pelelangan ikan yang dikelola oleh desa, jalan desa, dan kekayaan milik desa lainnya.

PP No. 47 Tahun 2015 pasal 1 ayat 9 tentang Peraturan Pelaksanaan UU No. 6 Tahun 2014 dijelaskan bahwa Alokasi Dana Desa (ADD adalah dana perimbangan yang diterima kabupaten/kota dalam anggaran pendapatan dan belanja daerah kabupaten/kota setelah dikurangi Dana Alokasi Khusus Sumber pendapatan desa dikelola melalui anggaran pendapatan dan belanja desa yang mana anggaran Pendapatan dan Belanja tersebut ditetapkan setiap tahun oleh kepala desa dengan peraturan desa selambatlambatnya satu bulan setelah ditetapkan APBD Kabupaten yang terdiri atas bagian penerimaan dan bagian pengeluaran. Bagian pengeluaran terdiri dari pengeluaran rutin dan pengeluaran pembangunan. Pengelolaan Anggaran Pendapatan dan Belanja Desa meliputi penyusunan, Pelaksanaan Tata Usaha Keuangan, perubahan serta perhitungan anggaran, pengelolaan anggaran dipertanggung jawabkan oleh kepala desa kepada BPD selambat-lambatnya tiga bulan setelah berakhir tahun aggaran. 
jmiap.ppj.unp.ac.id
Email : jianfis.unp@gmail.com

Vol.2 No.1 Maret 2019

\section{Pengaruh Sistem Pengendalian Intern terhadap Kinerja Pengelolaan Keuangan}

Menurut Sawyer (2005 : 57) Pengendalian intern berisi rencana organisasi dan semua metode terkoordinasi dan pengukuranpengukuran yang diterapkan diperusahaan yang bertujuan mengamankan aktiva, memeriksa akurasi dan keandalan data akuntansi, meningkatkan efesiensi operasional dan mendorong ketaatan terhadap kebijakan manajerial yang telah ditetapkan. seperti yang telah dikutip Hiro Tugiman (2004 : 12) Pengendalian yang baik meliputi: a) Kegiatan organisasi baik dan efisien.; b) Laporan keuangan atau informasi dari organisasi dapat dipercaya; c) Manajemen dalam organisasi patuh terhadap hukum dan perundangundangan yang berlaku.

Sistem pengendalian intern pemerintah meliputi berbagai kebijakan dan prosedur yang: a) Terkait dengan catatan keuangan; b) Menyediakan keyakinan yang memadai bahwa laporan tersebut telah sesuai dengan Standar Akuntansi Pemerintahan (SAP) dan penerimaan serta pengeluaran telah sesuai dengan otorisasi yang diberikan dan; c) Menyediakan keyakinan yang memadai atas keamanan aset daerah yang berdampak material pada laporan keuangan (Wilopo, 2006). Sedangkan Sukrisno Agoes (2008 : 80) menyebutkan pengendalian internal terdiri dari lima komponen yang saling berkaitan, sebagai berikut:

a) Lingkungan pengendalian (Control Enviroment) adalah suatu suasana organisasi yang mempengaruhi kesadaran akan suatu pengendalian dari sikap-sikap orang-orangnya serta suatu fondasi dari semua komponen pengendalian internal lainnya yang bersifat disiplin dan berstruktur.

b) Penilaian risiko (risk assessment) adalah suatu kebijakan dan prosedur yang dapat membantu suatu perusahaan dalam meyakinkan bahwa tugas dan perintah yang diberikan oleh manajemen telah dijalankan.

c) Aktivitas pengendalian (control activities) adalah suatu kebijakan dan prosedur yang dapat membantu suatu perusahan dalam meyakinkan bahwa tugas dan perintah yang diberikan oleh manajemen yang telah dijalankan.

d) Informasi dan komunikasi (information and communication) adalah pengidentifikasian, penangkapan dan pertukaran informasi dalam bentuk dan kerangka waktu yang membuat orang mampu melaksanakan tanggung jawabnya.

e) Pemantauan (mentoring) adalah suatu proses yang menilai kualitas kerja pengendalian internal pada suatu waktu serta melibatkan penilaian rancangan dan pengoperasian pengendalian dengan dasar waktu dan mengambil tindakan perbaikan yang diperlukan.

COSO (the committe of sponsoring organization of the treadway commission) memperkenalkan kerangka pengendalian yang terdiri dari 5 unsur sebagai berikut :

a. Lingkungan pengendalian, Lingkungan pengendalian melingkupi sikap para manajemen dan karyawan terhadap pentingnya pengendalian internal organisasi.

b. Penilaian risiko, Semua organisasi menghadapi risiko,yaitu dalam kondisi apapun yang namanya risiko pasti ada dalam suatu aktivitas, baik aktivitas yang berkaitan dengan bisnis maupun non bisnis. 
jmiap.ppj.unp.ac.id
Email : jianfis.unp@gmail.com

Vol.2 No.1 Maret 2019 c. Prosedur pengendalian, Prosedur pengendalian ditetapkan untuk standarisasi prose kerja, sehingga menjamin tercapainya tujuan perusahaan dan mencegah atau mendeteksi keterbatasan serta kesalahan.

d. Informasi dan komunikasi, menerapkan unsur-unsur yang penting dari pengendalian internal perusahaan. Informasi tentang lingkungan pengendalian, penilaian risiko, prosedur pengendalian dan pemantauan diperlukan oleh manajemen untuk pedoman operasi dan menjamin.

\section{Pengaruh Sistem Pengendalian Intern terhadap Kinerja}

Menurut Mardiasmo

Keberhasilan organisasi tidak semata mata diukur dari pespektif keuangan, karena sifat dasarnya yang tidak mencari profit, keberhasilan sebuah organisasi sektor publik juga harus diukur dari kinerjanya. Sedangkan menurut Arifin Sabeni dan Iman Gozali (1997 : 67) Hakikat pengawasan adalah mencegah terjadinya penyimpangan, pemborosan, penyelewengan, hambatan, kesalahan, dan kegagalan dalam mencapai tujuan dan pelaksanaan tugas -tugas organisasi

Menurut Wawan dan Lia (2009) Pengawasan intern adalah suatu alat pengawasan dari pemimpin organisasi untuk mengawasi kegiatan - kegiatan bawahannya apakah telah sesuai dengan rencana - rencana dan kebijakan yang telah ditentukan. Sedangkan Ihyaul Ulum MD (2004 : 82) menyebutkan Pengawasan atasan langsung dinilai paling efektif karena jarak antara subjek dan objek pengawasan paling dekat, sehingga dilaksanakan paling intensif.
Semakin

banyaknya permasalahan yang dihadapi organisasi pemerintah, maka semakin diperlukan keberadaan lembaga-lembaga pengawasan, namun apakah dengan adanya jumlah lembaga-lembaga pengawasan yang cukup banyak dan pelaksanaan pengawasan yang berlapis lapis dapat memperoleh hasil yang efektif karena semakin banyaknya waktu yang harus disediakan untuk melayani aparat pengawasan. Permasalahan inilah yang harus dipikirkan dan dicarikan solusinya untuk kepentingan bersama, apakah dengan melakukan penyederhanaan terhadap lembaga-lembaga pengawasan yang ada atau cukup membuat suatu aturan yang jelas dan tegas dengan tetap berpegang teguh pada upaya - upaya peningkatan kinerja pemerintah (Ihyaul Ulum MD, 2004 : 85)

Menurut penelitian yang telah dilakukan oleh Wawan dan Lia (2009) disimpulkan bahwa Pengawasan intern berpengaruh signifikan terhadap kinerja Pemerintah daerah, hal ini menunjukan pengawasan intern dapat memberikan dukungan terhadap responsivitas, responsibilitas, dan akuntabilitas pemerintah karena Semakin baik pengawasan intern yang dilaksanakan maka semakin memberikan dampak yang baik bagi kinerja Pemerintah daerah. Pengawasan intern berpengaruh terhadap kinerja pemerintah daerah, dan membantu para anggota organisasi melaksanakan tanggung jawab secara efektif serta mencapai kinerja yang lebih baik. Fungsi pengawasan intern adalah untuk memonitor apakah perilaku sudah berorientasi pada pencapaian kinerja yang baik,melakukan koreksi atau perilaku serta hasil yang menyimpang dari kinerja yang diinginkan (Abdul Rohmanm, 2009) 
jmiap.ppj.unp.ac.id
Email : jianfis.unp@gmail.com Vol.2 No.1 Maret 2019 pengendalian intern merupakan bagian utama dalam pengelolaan organisasi. pengendalian intern terdiri dari rencana-rencana, metode - metode, dan prosedur - prosedur yang digunakan untuk mencapai visi, misi, tujuan dan sasaran organisasi sehingga mendukung suatu sistem manajemen berbasis kinerja (Rahmadi Murwanto, 2012:195). Sedangkan menurut Mardiasmo (2002 : 143) untuk mewujudkan kinerja pemerintah daerah yang sesuai bias dilakukan dengan cara value for money (economy, efficiency, effective), serta perlu peningkatan fungsi aparat pemeriksaan fungsional pemerintah dilingkungan pemerintah daerah.

fungsi aparat pemeriksaan fungsional melaksanakan fungsi pengendalian intern (intern control) yang juga suatu fungsi penilaian yang independen dalam suatu organisasi untuk menguji dan mengevaluasi kegiatan organisasi yang dilakukan (Boynton, 2006). Sedangkan menurut dwiyanto (2006) kinerja birokrasi publik di Indonesia berbagai studi dan observasi tidak banyak mengalami perbaikan, bahkan menjadi semakin buruk. Berdasarkan penelitian yang dilakukan oleh Sarita (2012), Sistem Pengendalian Intern yang efektif akan berpengaruh terhadap kinerja. Sedangkan menurut Ramandei (2009), Dengan adanya sistem pengendalian intern yang efektif maka diperlukan partisipasi pimpinan dalam penyusunan anggaran, dan adanya kejelasan sasaran anggaran yang akan dilaksanakan, sehingga dapat berpengaruh terhadap kinerja. Pelaksanaan evaluasi anggaran dan umpan balik yang diperoleh diharapkan menjadi bahan penilaian terhadap keefektifan sistem pengendalian intern sehingga semakin efektif sistem pengendalian intern, maka semakin baik pula kinerjanya.

Sistem pengendalian intern adalah kebijakan dan prosedur yang dirancang untuk memberikan keyakinan yang memadai bagi manajemen bahwa organisasi mencapai tujuan dan sasarannya (Rai, 2008 : 283). Menurut PP No. 60 Tahun 2008 , sistem pengendalian intern adalah proses yang integral pada tindakan dan kegiatan yang dilakukan secara terus menerus oleh pimpinan dan seluruh pegawai untuk memberikan keyakinan memadai atas tercapainya tujuan organisasi melalui kegiatan yang efektif dan efisien, keandalan pelaporan keuangan, pengamanan asset negara dan ketaatan terhadap peraturan perundangundangan.

Alokasi biaya (ekonomi dan efesiensi) dan kualitas pelayanan merupakan indikator Pengukuran kinerja. Menurut Mardiasmo (2002 : 131 - 132), pengukuran kinerja dengan penilaian $3 \mathrm{E}$ (Ekonomis, Efisiensi, dan Efektivitas). Pengendalian intern adalah suatu proses yang dijalankan oleh dewan komisaris, manajemen dan personel lain, yang di desain untuk memberikan keyakinan memadai tentang pencapaian tiga golongan yaitu: a) Keandalan informasi keuangan, b). Kepatuhan kepada hukum dan peraturan yang berlaku, c) Efektifitas dan efisiensi operasi (Mulyadi, 2002 : 216).

Banyak penelitian yang dilakukan oleh para peneliti tentang pengaruh sistem pengendalian intern terhadap kinerja seseorang atau kinerja organisasi, termasuk kinerja dalam pengelolaan keuangan. Temuan penelitian tersebut menunjukkan hasil yang positif. Berdasarkan penelitian yang telah dilakukan Rina Tresnawati (2012), yang berjudul Pengaruh Efektifitas 
jmiap.ppj.unp.ac.id
Email : jianfis.unp@gmail.com

Vol.2 No.1 Maret 2019
Pengendalian Intern terhadap Kinerja Instansi Pemerintah Dinas Pendapatan Daerah Kota Bandung, hasil penelitian ini menunjukkan bahwa sistem pengendalian intern berpengaruh positif terhadap kinerja di Dinas Pendapatan Daerah Kota Bandung. Selain itu, Vetty Rebecca TH Panjaitan (2015) dalam penelitian nya yang berjudul Pengaruh Pengendalian Intern, Kompetensi Sumber Daya Manusia, Komitment Organisasi dan Budaya Organisasi terhadap Kinerja Bagian Keuangan (studi pada SKPD Kota Dumai), hasil penelitian ini menunjukkan bahwa sistem pengendalian intern berpengaruh positif terhadap kinerja bagian keuangan (studi pada SKPD Kota Dumai). Disamping itu, Bulan Tati Fitria dan Kania Prissilia (2013) dalam penelitiannya yang berjudul Pengaruh Pengendalian Intern terhadap Efektivitas Target Produksi PT. Lucas Djaja Pharmaceutical Industry Bandung Jawa Barat, hasil penelitian ini menjelaskan bahwa sistem pengendalian intern berpengaruh positif terhadap efektivitas target produksi PT. Lucas Djaja Pharmaceutical Industry Bandung. serta penelitian Astri Kuswandari (2018) yang berjudul Pengaruh Pengawasan Intern Dan Pengelolaan Keuangan Daerah Terhadap Kinerja Pemerintah Daerah (Survei Pada Dinas SKPD Pemerintah Kota Bandung), yang hasil penelitian ini menjelaskan terdapat pengaruh positif sistem pengendalian intern terhadap Kinerja Pemerintah Daerah (Survei Pada Dinas SKPD Pemerintah Kota Bandung). Namun demikian, terdapat hasil yang berbeda pada Penelitian Shodiq (2001) serta Boritz dan Jee (2007) yaitu tidak adanya dukungan terhadap kinerja keuangan daerah.

pada umumnya hasil penelitian terdahulu menunjukkan sistem pengendalian intern berpengaruh positif terhadap kinerja pegawai dalam melaksanakan pekerjaan. Komponenkomponen dalam Pengendalian Intern seperti lingkungan pengendalian yang baik, akan memberikan kontribusi baik dalam menciptakan suasana kerja sehingga dapat mendorong karyawan untuk meningkatkan kinerja. Pemerintah Daerah diharapkan agar tetap waspada terhadap segala resiko yang akan dihadapi nantinya dengan adanya penaksiran resiko maka karyawan dapat lebih meningkatkan kinerja. Selain itu, Informasi dan komunikasi akan memberikan dampak baik bagi peningkatan kinerja karena semua karyawan memperoleh dan bertukar informasi yang diperlukan dalam melakukan aktivitas operasional perusahaan serta aktivitas pengendalian mendorong karyawan mentaati dan melaksanakan peraturan dan standar kerja yang sudah ditetapkan. Terakhir, Pemantauan yang baik akan membuat karyawan untuk lebih disiplin dalam bekerja.

\section{Metode Penelitian}

Penelitian ini menggunakan pendekatan kuantitatif dengan jenis penelitian asosiatif. Penelitian ini dilaksanakan pada beberapa kenagarian di Kabupaten Tanah Datar. Variabel dalam penelitian ini adalah sistem pengendalian intern dan kinerja pengelolaan keuangan nigari serta Populasi dalam penelitian ini terdiri dari 600 orang. Sampel penelitian diambil dengan menggunakan rumus Slovin dan teknik multistage random sampling, sehingga didapatkan responden sebanyak 248 orang.

Pengumpulan data dilakukan dengan menggunakan angket (kuesioner). Untuk item pernyataan dalam kuesioner dibuat dengan menggunakan skala pengukuran Likert. Data yang diperoleh kemudian 
JMIAP

jmiap.ppj.unp.ac.id
Email : jianfis.unp@gmail.com

Vol.2 No.1 Maret 2019 dianalisis dengan menggunakan teknik regresi linear berganda, Setelah dianalisis maka hasil analisis diinterpretasikan dan dibahas dengan menggunakan teori yang telah dikemukakan dalam kajian kepustakaan.

\section{Hasil Penelitian dan Pembahasan}

\section{Hasil Penelitian}

Berdasarkan hasil olah data yang telah dilakukan, maka dapat dilihat gambaran hasil tentang pengaruh Sistem Pengendalian Intern terhadap Pengelolaan Keuangan Nagari, seperti tergambar dalam Tabel 1 dan Tabel 2 berikut ini

Tabel 1. Pengaruh Sistem Pengendalian Intern secara simultan terhadap Kinerja Aparatur Pemerintahan Nagari dalam Pengelolaan Keuangan Nagari

\begin{tabular}{|c|c|c|c|c|c|}
\hline \multicolumn{6}{|c|}{ Model Summary ${ }^{\mathbf{b}}$} \\
\hline Model & $\mathbf{R}$ & R Square & $\begin{array}{l}\text { Adjusted R } \\
\text { Square }\end{array}$ & $\begin{array}{l}\text { Std. Error of } \\
\text { the Estimate }\end{array}$ & Durbin-Watson \\
\hline 1 & $379^{\mathrm{a}}$ & ,143 & , 140 & ,32167 & 1,775 \\
\hline
\end{tabular}

Tabel 2. Hasil Uji Anova (F) Pengaruh Variabel Sistem Pengendalian Intern terhadap Kinerja Aparatur Pemerintahan Nagari dalam Pengelolaan Keuangan Nagari

\begin{tabular}{llcrrrr}
\hline \multicolumn{8}{c}{ ANOVA $^{\mathbf{a}}$} \\
\hline \multirow{4}{*}{1} & Model & Sum of Squares & Df & Mean Square & \multicolumn{1}{c}{ F } & \multicolumn{1}{c}{ Sig. } \\
\hline & Regression & 4,257 & 1 & 4,257 & 41,136 &, $000^{\mathrm{b}}$ \\
& Residual & 25,455 & 246 &, 103 & & \\
& Total & 29,711 & 247 & & & \\
\hline
\end{tabular}

a. Dependent Variable: Rata-rata pengelolaan keuangan nagari

b. Predictors: (Constant), rata-rata sistem pengendalian intern

Berdasarkan Tabel 1 di atas dapat dijelaskan bahwa nilai Adjusted $R$ Square yang diperoleh dari analisis regresi sebesar 0,140. Artinya, besarnya pengaruh variabel sistem pengendalian intern yang mencakup lima sub variable (tahap perencanaan, pelaksanaan, penatausahaan, pelaporan dan pertanggung jawaban secara simultan) terhadap kinerja aparatur pemerintahan nagari dalam pengelolaan keuangan nagari adalah sebesar $14,0 \%$. Sementara sisanya sebesar $86 \%$ dipengaruhi oleh faktor lain yang tidak diteliti dalam penelitian ini. Selain itu, bila diperhatikan hasil uji Anova pada Tabel 2 di atas dapat pula dilihat bahwa hasil atau angka signifikansi pengaruh menunjukkan angka $0,000^{\mathrm{b}}$. Artinya, kebenaran kesimpulan hasil uji regresi ini dapat dipercaya sampai $100 \%$.

Selanjutnya, rumusan masalah yang ingin dijawab dalam penelitian adalah: apakah terdapat pengaruh secara sendiri-sendiri dari aspek tahap perencanaan, taha pelaksanaan, tahap penatausahaan, tahap pelaporan dan tahap pertanggung jawaban (sebagai sub 
JMIAP

jmiap.ppj.unp.ac.id
Email : jianfis.unp@gmail.com

Vol.2 No.1 Maret 2019 variabel sistem pengendalian intern) terhadap kinerja aparatur pemerintahan nagari dalam pengelolaan keuangan nagari di Kabupaten Tanah Datar?
Secara ringkas, hasil pengujian regresi secara parsial (sendiri-sendiri) dapat dilihat pada Tabel 3 berikut ini.

Tabel 3. Pengaruh Pengendalian Intern secara parsial terhadap Kinerja Aparatur Pemerintahan Nagari dalam Pengelolaan Keuangan Nagari

\begin{tabular}{lccrc}
\hline \multicolumn{1}{c}{ Sub Variabel } & R & R Square & $\begin{array}{c}\text { Adjusted R } \\
\text { Square }\end{array}$ & Sig. \\
\hline Tahap perencanaan & $.318^{\mathrm{a}}$ & .101 & .098 & $.000^{\mathrm{b}}$ \\
Tahap pelaksanaan & $.378^{\mathrm{a}}$ & .143 & .139 & $.000^{\mathrm{b}}$ \\
Tahap penatausahaan & $.328^{\mathrm{a}}$ & .107 & .104 & $.000^{\mathrm{b}}$ \\
Tahap pelaporan & $.301^{\mathrm{a}}$ & .091 & .087 & $.000^{\mathrm{b}}$ \\
Tahap pertanggung jawaban & $.262^{\mathrm{a}}$ & .069 & .065 & $.000^{\mathrm{b}}$ \\
\hline
\end{tabular}

Berdasarkan Tabel 3 di atas dapat dipahami bahwa, nilai Adjusted $R$ Square untuk sub variabel tahap perencanaan adalah sebesar 0,098. Hal ini berarti bahwa pengaruh tahap perencanaan terhadap pengelolaan keuangan nagari adalah sebesar $9,8 \%$. Sedangkan sisanya sebesar 90,2\% dipengaruhi oleh variabel lain. Selanjutnya nilai Adjusted $R$ Square untuk sub variabel tahap pelaksanaan adalah sebesar 0,139. Hal ini berarti bahwa pengaruh keterampilan terhadap pengelolaan keuangan nagari adalah sebesar $13,9 \%$ dan sisanya sisanya sebesar $86,1 \%$ dipengaruhi oleh variabel lain. Sedangkan nilai Adjusted $R$ Square untuk sub variabel tahap penatausahaan adalah sebesar 0,104. Hal ini berarti bahwa pengaruh tahap penatausahaan terhadap pengelolaan keuangan nagari adalah sebesar $10,4 \%$ dan sisanya sisanya sebesar $89,6 \%$ dipengaruhi oleh variabel lain.

Sedangkan nilai Adjusted $R$ Square untuk sub variabel tahap pelaporan adalah sebesar 0,087. Hal ini berarti bahwa pengaruh tahap pelaporan terhadap pengelolaan keuangan nagari adalah sebesar $8,7 \%$ dan sisanya sisanya sebesar $91,3 \%$ dipengaruhi oleh variabel lain. Sedangkan nilai Adjusted R Square untuk sub variabel tahap pertanggung jawaban adalah sebesar 0,065. Hal ini berarti bahwa pengaruh tahap pertanggung jawaban terhadap pengelolaan keuangan nagari adalah sebesar $6,5 \%$ dan sisanya sisanya sebesar 93,5\% dipengaruhi oleh variabel lain.

Selain itu, bila diperhatikan hasil uji Anova pada hasil atau angka signifikansi pengaruh menunjukkan angka $0,000^{\mathrm{b}}$ untuk semua subvariabel.Ini berarti bahwa kebenaran kesimpulan hasil uji regresi ini dapat pula dipercaya sampai $100 \%$.

\section{Pembahasan}

Hasil penelitian tentang pengaruh sistem pengendalian intern terhadap kinerja aparatur pemerintahan nagari dalam pengelolaan keuangan nagari di Kabupaten Tanah Datar telah membuktikan bahwa terdapat pengaruh sistem pengendalian intern terhadap kinerja aparatur pemerintahan nagari dalam pengelolaan keuangan nagari di Kabupaten Tanah Datar, baik secara simultan maupun secara parsial dari kelima sub variabel sistem pengendalian 
jmiap.ppj.unp.ac.id
Email : jianfis.unp@gmail.com

Vol.2 No.1 Maret 2019 intern, yaitu tahap perencanaan, pelaksanaan, penatausahaan, pelaporan dan pertanggung jawaban Secara bersama-sama pengaruh tahap perencanaan, tahap pelaksanaan, tahap penatausahaan, tahap pelaporan dan tahap pertanggung jawaban terhadap kinerja aparatur pemerintahan nagari dalam pengelolaan keuangan nagari di Kabupaten Tanah Datar menghasilkan angka signifikansi 0,000 dan nilai Adjust $R$ Square sebesar 0,140 sehingga dapat dikatakan bahwa kontribusinya adalah sebesar $14,0 \%$ dan nilai $\mathrm{R}$ sebesar 0,379 yang berarti bahwa kekuatan variabel sistem pengendalian intern terhadap kinerja aparatur pemerintahan nagari dalam pengelolaan keuangan nagari di Kabupaten Tanah Datar sebesar 37,9\%. Dari penjelasan di atas dapat ditarik kesimpulan bahwa baik secara parsial maupun secara bersama-sama sistem pengendalian intern memiliki pengaruh secara signifikan terhadap kinerja aparatur pemerintahan nagari dalam pengelolaan keuangan nagari di Kabupaten Tanah Datar.

Penelitian ini dapat membuktikan dan ikut memperkuat ketentuan, teoriteori, dan temuan penelitian yang sudah ada, seperti PP No. 60 tahun 2008 bahwa Sistem Pengendalian Intern Pemerintah merupakan proses yang integral pada tindakan dan kegiatan yang dilakukan secara terus-menerus oleh pimpinan dan seluruh para pegawai untuk memberikan keyakinan memadai atas tercapainya tujuan organisasi melalui kegiatan yang efektif dan efesien, keandalan laporan

\section{Penutup}

Berdasarkan hasil temuan dan pembahasan yang telah dijabarkan, dapat disimpulkan dan diberikan saran bahwa: keuangan, pengamanan aset negara dan ketaatan terhadap peraturan perundangundangan. Disamping itu, hasil penelitian ini juga ikut mendukung dan memperkuat teori dikemukakan oleh Rahmadi Murwanto (2012:195) pengendalian intern merupakan bagian utama dalam pengelolaan suatu organisasi, pengendalian intern juga terdiri dari rencana-rencana, metode-metode, dan prosedur-prosedur yang digunakan untuk mencapai visi, misi, tujuan dan sasaran organisasi sehingga mendukung suatu sistem manajemen berbasis kinerja.

Selain itu hasil penelitian ini juga sejalan dengan/memperkuat hasil penelitian yang dikemukakan oleh Rina Tresnawati (2012) yang mana hasil penelitian ini menunjukkan bahwa terdapat pengaruh positif sistem pengendalian intern terhadap kinerja pada Dinas Pendapatan Daerah Kota Bandung. Selain itu, hasil penelitan Vetty Rebecca TH Panjaitan (2015), menunjukkan bahwa terdapat pengaruh positif sistem pengendalian intern terhadap kinerja bagian keuangan (studi pada SKPD Kota Dumai). Di samping itu, hasil penelitian Bulan Tati Fitria Dan Kania Prissilia (2013), berpengaruh positif sistem pengendalian intern terhadap efektivitas target produksi PT. Lucas Djaja Pharmaceutical Industry Bandung serta penelitian Astri Kuswandari (2018), menjelaskan bahwa terdapat pengaruh positif sistem pengendalian intern terhadapKinerja Pemerintah Daerah (Survei Pada Dinas SKPD Pemerintah Kota Bandung).

1. Pengaruh pengendalian intern dalam tahap perencanaan (X1) terhadap pengelolaan keuangan nagari memiliki nilai Adjust $R$ Square 0,098 sehingga kontribusi lingkungan pengendalian terhadap pengelolaan keuangan nagari sebesar $9,8 \%$, Selanjutnya Pengaruh 
jmiap.ppj.unp.ac.id
Email : jianfis.unp@gmail.com Vol.2 No.1 Maret 2019 sistem pengendalian intern dalam tahap pelaksanaan (X2) terhadap pengelolaan keuangan nagari memiliki nilai Adjust $R$ Square 0,139 sehingga kontribusi keterampilan terhadap pengelolaan keuangan nagari sebesar $13,9 \%$, di samping itu, Pengaruh tahap penatausahaan (X3) terhadap pengelolaan keuangan nagari memiliki nilai Adjust $R$ Square sebesar 0,104\% sehingga kontribusi sikap terhadap pengelolaan keuangan nagari sebesar 10,4\%. Selanjutnya Pengaruh tahap pelaporan (X4) terhadap pengelolaan keuangan nagari memiliki nilai Adjust $R$ Square sebesar 0,087 sehingga kontribusi sikap terhadap pengelolaan keuangan nagari sebesar $8,7 \%$. Disamping itu, Pengaruh tahap pertanggungjawaban (X5) terhadap pengelolaan keuangan nagari memiliki nilai Adjust $R$ Square sebesar 0,065 sehingga kontribusi sikap terhadap pengelolaan keuangan nagari sebesar $6,5 \%$ serta Pengaruh sistem pengendalian intern terhadap kinerja aparatur pemerintaha nagari dalam pengelolaan keuangan nagari di Kabupaten Tanah Datar dengan nilai Adjust $R$ Square sebesar $0,014 \%$ sehingga kontribusinya sebesar $14,0 \%$ dan nilai $\mathrm{R}$ sebesar 0,379 yang artinya kekuatan variabel sistem pengendalian intern terhadap pengelolaan keuangan nagari sebesar $37,9 \%$ serta dapat dipercaya $100 \%$

2. Dari hasil temuan menunjukan bahwa sistem pengendalian intern dalam tahap perencanaan, tahap pelaksanaan, tahap penatausahaan, tahap pelaporan dan tahap pertanggung jawaban baik secara parsial maupun silmutan berpengaruh terhadap kinerja aparatur pemerintahan nagari dalam pengelolaan keuangan nagari. Dengan demikian disarankan kepada setiap
Aparatur Pemerintahan Nagari agar lebih memperhatikan dan meningkatkan pengendalian intern dalam terhadap pengelolaan keuangan nagari demi meningkatkan kinerja aparatur pemerintahan nagari.

3. Peneliti menyadari bahwa hasil penelitian ini masih memiliki kelemahan tertentu, maka dari itu diharapkan kepada peneliti selanjutnya untuk lebih menyempurnakan penelitian ini.

\section{Daftar Kepustakaan}

Fitria, B. T. (2013). Pengaruh Pengendalian Intern Terhadap Efektivitas Target Produksi PT. Lucas Djaja Pharmaceutical Industry Bandung Jawa Barat. Jurnal Ekonomi, Bisnis \& Entrepreneurship, 7(1), 41-51. https://doi.org/10.1007/978-3-31957264-2

Hamidah, A. S. (2011). Pengaruh Pengendalian Intern Dan Pelaksanaan Sistem Akuntansi Keuangan Daerah Terhadap Kinerja Instansi Pemerintah, $1-16$.

Kuswandari, A. (2014). Pengaruh Pengawasan Intern Dan Pengelolaan Keuangan Daerah Terhadap Kinerja Pemerintah Daerah (Studi Empiris Pada SKPD Pemerintah Provinsi Sumatera Barat), 1-23.

Mardiasmo.2002.2004.Akuntansi Sektor Publik. Andi Offset. Yogyakarta.

Muhammad Arif. 2007. Tata Cara Pengelolaan Keuangan Desa Dan Pengelolaan Kekayaan Desa. Pekanbaru: Red Post Press

Mulyani, P., \& Suryawati, R. F. (2011). Analisis peran dan fungsi sistem pengendalian intern pemerintah (SPIP/PP No.60 Tahun 2008) dalam 
jmiap.ppj.unp.ac.id
Email : jianfis.unp@gmail.com Vol.2 No.1 Maret 2019 meminimalisasi tingkat salah saji pencatatan akuntansi keuangan pemerintah daerah. Jurnal Organisasi Dan Manajemen, 7(2), 102-116. https://doi.org/10.1145/2480362.24803 79

Panjaitan, V. R., Sulasilatri, \& Azlina, N. (2015). Pengaruh Pengendalian Intern, Kompetensi Sumber Daya Manusia, Komitmen Organisasi Dan Budaya Organisasi Terhadap Kinerja Bagian Keuangan (Studi Pada Skpd Kota Dumai). Jom FEKON, 2(2), 1-15.

Peraturan Menteri Dalam Negeri Nomor 13 Tahun 2006 Tentang Pedoman Pengelolaan Keuangan Daerah. (2006), (1), 1-5.

Peraturan Mentri Dalam Negeri Nomor 113 Tahun 2014 Tentang Pengelolaan Keuangan Desa. (2014), 1-16. https://doi.org/10.1016/0034-

5687(85)90130-6

Peraturan Pemerintah Nomor 47 Tahun 2015 Tentang Peraturan Pelaksanaan Undang - Undang Nomor 6 Tahun 2014 Tentang Desa. (2015).

Peraturan Pemerintah Republik Indonesia nomor 60 Tahun 2008 Tentang Sistem Pengendalian Intern. (2008), 282.

PUJIONO, D. S. (2016). Pengaruh Sistem Pengendalian Intern Terhadap Pengelolaan Keuangan Daerah Serta Kinerja Pemerintah Daerah, 10(1), 6881.

Rochmansjyah Soleh. 2015. Pengelolaan Keuangan Desa. Bandung: Fokus Media

Rozali Abdullah. 2011. Pelaksanaan Otonomi Luas dengan Pemilihan Kepala Daerah Secara Lansung. Jakarta: Rajawali Pers.

Sari, P. W. (2008). DAN PENGAWASAN INTERNAL, 1-13.
Tresnawati, R. (2012). Pengaruh efektifitas pengendalian intern terhadap kinerja instansi pemerintah di dinas pendapatan daerah kota bandung, 139-151.

Undang - Undang Nomor 17 Tahun 2003 Tentang Keuangan Negara. (2003), (1), $1-40$.

Wartaandalas. 2018. "Wali Nagari Sugayang Diduga Tersandung Kasus Penggelapan Dana

Nagari".http://wartaandalas.com/beritawali-nagari-sungayang-di-dugatersandung-kasus penggelapan-dananagari.html. Diakses pada tanggal 14 Maret 2018. 